Reprod. Nutr. Dévelop., 1987, 27 (6), 1023-1040.

\title{
Pulsatile LH secretion during the preovulatory surge in the ewe : experimental observations and theoretical considerations
}

\author{
G. B. MARTIN $\left({ }^{3}\right)\left({ }^{*}\right)$, G. B. THOMAS $\left({ }^{1,4}\right)$, M. TEROUI $\left({ }^{2}\right)$, Pamela WARNER
}

MRC Reproductive Biology Unit, Centre for Reproductive Biology, 37 Chalmers Street, Edinburgh EH3 9EW, U.K.

(1) School of Agriculture (Animal Science), University of WA, Nedlands, Western Australia 6009.

(2) Station de Physiologie de la Reproduction, I.N.R.A., Nouzilly, 37380 Monnaie, France.

Summary. The secretion of LH during the preovulatory surge has been shown to be pulsatile in several species. We confirmed this phenomenon in intact ewes in two experiments in which we studied the LH surge in detail. In the first experiment, the levels of $\mathrm{LH}$ were measured in discrete blood samples taken every $5 \mathrm{~min}$ around the onset of oestrus in 5 intact Merino ewes. For 2-5 h immediately prior to the onset of the surge, the median pulse interval was 17.5 min (range 10-55) and the median pulse amplitude was $0.70 \mathrm{ng} / \mathrm{ml}$ (range 0.28-1.33 $\mathrm{ng} / \mathrm{ml}$ ). During the ascending phase of the surge, the pulse interval did not change significantly (median $18.3 \mathrm{~min}$ ) but the median pulse amplitude increased 20 fold to $18.0 \mathrm{ng} / \mathrm{ml}$. During the descending phase, the median pulse interval was $22.5 \mathrm{~min}$ and the median amplitude decreased to $8.1 \mathrm{ng} / \mathrm{ml}(\mathrm{P}<0.005)$. During the surge, intervals of $10 \mathrm{~min}$ and amplitudes over $30 \mathrm{ng} / \mathrm{ml}$ were common. In the second experiment with 2 oestrous Romanov $x$ Préalpes-du-Sud ewes, blood was withdrawn continuously and samples were pooled over 4 min periods for 19-27 h. In the resulting profiles, individual pulses were better defined but the pulse frequencies (median interval 15.2 min during ascending phase) and amplitudes (median $35.0 \mathrm{ng} / \mathrm{ml}$ ) varied in similar fashion to the Merinos.

Using a simple mathematical description of pulsatile secretion, and assuming that LH is only released in pulses, we also found that the high concentrations normally achieved during the surge can only be explained by pulse frequencies and amplitudes well above those normally observed in other physiological situations, including the follicular phase or following ovariectomy. These findings strongly support the experimental data and the combined results of the two studies suggest that the initiation and execution of the LH surge is probably accomplished by changes in the amplitude of pulses. A high frequency is also essential and our data suggest that it may be established some time before the onset of the surge proper, but this requires confirmation. Respectively, the changes in amplitude

Present Address : Australia.

(3) G. B. Martin : School of Agriculture (Animal Science), University of WA, Nedlands, WA 6009

(4) G. B. Thomas: Medical Research Centre, Prince Henry's Hospital, St. Kilda Road, Melbourne, Victoria 3004, Australia.

$\left(^{*}\right)$ Correspondence : Dr. G. B. Martin. 
and frequency reflect the pituitary and hypothalamic components of the positive feedback mechanism. The theoretical study suggested that a change in clearance rate could also contribute to the surge and this awaits further investigation.

\section{Introduction.}

The entire ewe has long been considered to exhibit two modes of LH secretion : a tonic mode which continues throughout most of the oestrous cycle and controls follicular and luteal activity, and a surge mode which comes into play once each cycle at the onset of oestrus to induce ovulation and luteinization. Historically, the surge was described first because it lasted many hours and was large enough to be detected in peripheral plasma with the first immunoassays (Geschwind and Dewey, 1968 ; Pelletier et al., 1968 ; Niswender et al., 1968). Tonic secretion was at first thought to be low and continuous (e.g. Reeves et al., 1970 ; Scaramuzzi et al., 1970) but more frequent samples were taken in subsequent studies and it was found to be pulsatile (Scaramuzzi and Martensz, 1975). It is now known that the frequency and amplitude of the pulses vary according to the phase of the reproductive cycle and the state of the environment (Martin, 1984).

Detailed examination of the preovulatory LH profiles of women, cows rats and monkeys has revealed that the surge is also composed of pulses rather than a massive continuous release of hormone (Midgley and Jaffe, 1971 ; Rahe et al., 1980 ; Gallo, 1981 ; Marut et al., 1981 ; Walters and Schallenberger, 1984). The pulses are very frequent and of high amplitude compared to those secreted tonically, and it has been proposed that the changes in $\mathrm{LH}$ concentration that describe the surge can be entirely explained by changes in pulse frequency and amplitude (Gallo, 1981).

On occasions, frequent blood samples have been collected inadvertently near the onset of the surge in ewes, and from the resulting profiles it appears that the surge is also composed of pulses in this species (Baird, 1978 ; Poindron et al., 1980 ; Karsch et al., 1983). The frequency of LH pulses is determined entirely by the hypothalamus through its control over the frequency of the pulses of gonadotrophin-releasing hormone $(\mathrm{GnRH})$, while pulse amplitude is potentially determined by both hypothalamic (the amplitude of the GnRH pulses) and pituitary factors (the responsiveness of the gonadotrophs to GnRH) (review : Martin, 1984). The observation that the LH surge is composed of pulses therefore raises fundamental questions concerning the respective contributions of the hypothalamus and the pituitary gland in the secretion of the surge.

In the present study, we have recorded the changes in pulse amplitude and frequency around the time of the endogenously-generated $\mathrm{LH}$ surge in oestrous ewes, and we have determined the theoretical combinations of pulse variables (amplitudes and frequencies) which would be required to reach the high concentrations of LH normally observed during the surge. Comparison of these findings with the experimental data have led us to conclude that the preovulatory surge is probably due to a profound increase in LH pulse amplitude superimposed on a background of high pulse frequency. 


\section{Material and Methods.}

\section{a) Empirical studies}

\section{Experiment 1}

Anima/s. - To minimize the duration of sampling, we took advantage of the close synchrony that exists between the onsets of the $\mathrm{LH}$ surge and oestrus in the ewe (review : Martin, 1984). Twenty mature, entire Merino ewes were treated with intravaginal sponges containing $30 \mathrm{mg}$ of fluogestone acetate (Chronogest 30 , Intervet) and 13 days later they received indwelling jugular cannulae. The sponges were withdrawn the following day and the ewes were placed in a pen with two vasectomized rams wearing marking crayons. At 06:00 h, $36 \mathrm{~h}$ after sponge withdrawal, the ewes that had been detected in oestrus by the rams were removed and the remaining ewes were observed continuously for signs of oestrous behaviour. The next five ewes to show standing oestrus were also removed and blood $(2 \mathrm{ml}$ ) was sampled from them every $5 \mathrm{~min}$ untill 17:00 h when samples had been collected from individual ewes for 6-10 $\mathrm{h}$.

Radioimmunoassay of $L H$. - The double antibody assay has been described in detail by Martin et al. (1980). In brief : $10 \mu \mathrm{l}$ (surge) or $200 \mu \mathrm{l}$ (late follicular phase) aliquots of each sample were assayed in duplicate ; for reference and iodination we used the preparation CNRS-M3 (activity $1.8 \mathrm{i} . \mathrm{u} . / \mathrm{mg} \mathrm{NIH-LH-S1)} \mathrm{kindly}$ supplied by $M$. Jutisz (CNRS, Gif-sur-Yvette, France); the limit of detection of the standard curve was $0.36 \mathrm{ng} / \mathrm{ml}$; six $200 \mu$ l replicates of 3 pooled samples (concentrations : $0.99 \pm 0.16 \mathrm{ng} / \mathrm{ml} ; 3.45 \pm 0.11 \mathrm{ng} / \mathrm{ml}:$ and $10.41 \pm 0.40 \mathrm{ng} / \mathrm{ml}$, mean \pm SEM) were used to estimate the coefficients of variation within $(12.1 \pm 1.4 \% ; 5.1 \pm 0.5 \% ; 5.3 \pm 0.6 \%)$ and between assays $13.6 \%$; $7.6 \% ; 5.1 \%)$.

\section{Experiment 2}

Animals and sampling. - 2 cyclic crossbred (Romanov x Préalpes-du-Sud) ewes were given an indwelling catheter in an external jugular vein about 3 days before the expected onset of oestrus. The animals were heparinized (10 000 i.u. every $2 \mathrm{~h}$ ) and connected to a peristaltic pump. On the expected day of oestrus, blood was aspirated at a constant rate for 19-27 $\mathrm{h}$ and aliquots were pooled over $4 \mathrm{~min}$ periods with the aid of a fraction collector. Plasma was separated and frozen until assayed.

Radioimmunoassay of $\angle H$. - The double antibody assay was initially developed by Pelletier et al. (1968) but has recently been modified to improve sensitivity (Pelletier et al., 1982). Only small amounts of plasma were available so single aliquots of $50 \mu \mathrm{l}$ were assayed. The hormone preparation described for experiment 1 was also used in this assay, which contained all the samples from the experiment and had a limit of detection was $0.54 \mathrm{ng} / \mathrm{ml}$. In contrast to the routine of the laboratory in which experiment 1 was carried out, the within-assay variation 
was determined from the variation around each point on the standard curve (4 replicates). This does not take account of the effects of plasma but does allow the variation to be measured at all points on the curve, thus aiding in the detection of pulses at widely varying concentrations of hormone. The coefficient of variation decreased from $45 \%$ at $0.65 \mathrm{ng} / \mathrm{ml}\left\langle\mathrm{B} / \mathrm{B}_{0}=94 \%\right)$ to $4 \%$ at $10 \mathrm{ng} / \mathrm{ml}\left(\mathrm{B} / \mathrm{B}_{0}=72 \%\right)$, and then increased to $27 \%$ at $80 \mathrm{ng} / \mathrm{ml}\left(\mathrm{B} / \mathrm{B}_{0}=\right.$ $50 \%)$.

\section{b) Data analysis}

A pulse was defined as any increase in $\mathrm{LH}$ concentration which exceeded the sum of the assay errors (coefficients of variation) for the lowest (nadir) and highest (peak) samples, and which was followed by a decline in concentration that also exceeded the sum of the assay errors. This is essentially the definition described in detail by Martin et al. (1983), except that the maximum time allowed between a significant increase and significant decrease was extended to 5 sampling intervals. Pulse interval was estimated from the number of samples between successive significant peaks and pulse amplitude was estimated by subtracting the nadir concentration (the lowest value between successive significant peaks) from the pulse height (absolute concentration at the pulse peak). The onset of the LH surge was arbitrarily defined as the time at which the pulse height increased above $10 \mathrm{ng} / \mathrm{ml}$. The peak of the surge was the sample with the highest concentration of $\mathrm{LH}$, so the ascending and descending phases were the periods either side of this point during which the level of $\mathrm{LH}$ was more than $10 \mathrm{ng} / \mathrm{ml}$.

In many instances, the data were not normally distributed so medians and ranges are provided, and the frequency distributions of pulse intervals and amplitudes were compared, between sections of the hormone profiles, using Chisquared analysis. Elsewhere, means and standard errors are quoted. Because different assay methods were required for the follicular and surge sections of the profiles in experiment 1 , statistical comparison of the phases for pulse amplitudes was not possible. Within phases, changes in amplitude from one pule to the next were tested by paired analysis of variance.

\section{c) Theoretical study}

It is generally accepted that LH is secreted tonically as pulses. Indeed, there appears to be little non-pulsatile "leakage " and between pulses the net release from the head into jugular blood is negative (Rasmussen and Malven, 1982). From the peak of the pulse, the hormone level declines in an approximately log-linear fashion until the onset of the next pulse. In order to represent pulses in simple mathematical terms for the present study, we made the following assumptions : 1) $\mathrm{LH}$ is secreted into only one compartment (the plasma) and there is only one rate constant (the half-life) governing the clearance i.e., only one site of clearance. Most LH is catabolized by the liver, but it is to be expected that some of the hormone would be absorbed and metabolized at other sites and some would diffuse into extravascular compartments (Rasmussen and Malven, 1982). Mclntosh and Mclntosh (1980) discuss this in some depth with respect to 
pregnant mare's serum gonadotrophin, which has more than one rate constant for clearance in sheep.

2) The duration of secretion is very short compared to the duration of the pulse, the sampling interval and the half-life. Thus, it is assumed that maximum $\mathrm{LH}$ concentration is reached at $\mathrm{t}=0 \mathrm{~min}$ and the subsequent decline reflects clearance alone, rather than a summation of clearance and secretion. This is probably a fair approximation as $\mathrm{LH}$ is secreted for only 2-6 $\mathrm{min}$ at the onset of the pulse (Rasmussen and Malven, 1982). However, when the pulse interval becomes short, even 2 min may become a significant proportion of the duration of the pulse.

3) Mixing of the hormone is complete and takes a very short time relative to sampling and clearance.

Under these assumptions, most of which have been discussed by Mclntosh and Mclntosh (1980, pp. 115-119), each LH pulse consists of an instantaneous increase in concentration followed by a simple log-linear decline which continues until the onset of the next pulse. The theoretical heights of pulses and nadirs have been calculated using the mathematical model described in the Annex for the different values of the interval between pulses (I) and pulse amplitude (A). In brief, starting with a conveniently chosen concentration (S), the nadir (N) after the first pulse is given by

$$
N=\frac{(S+A)}{e^{b l}}
$$

where $e$ is the natural exponent (2.718), the constant, $b=\frac{\ln 2}{t_{1 / 2}}$ and $t_{1 / 2}$ is the time needed to lose half of $C$ (the half-life). As the number of pulses in a series increases, the nadir increases but stabilizes at an asymptotic (asymp) maximum (fig. 1), given by the formula

$$
\mathrm{N}_{\text {asymp }}=\frac{A}{\mathrm{e}^{(\mathrm{bl}-1)}}
$$

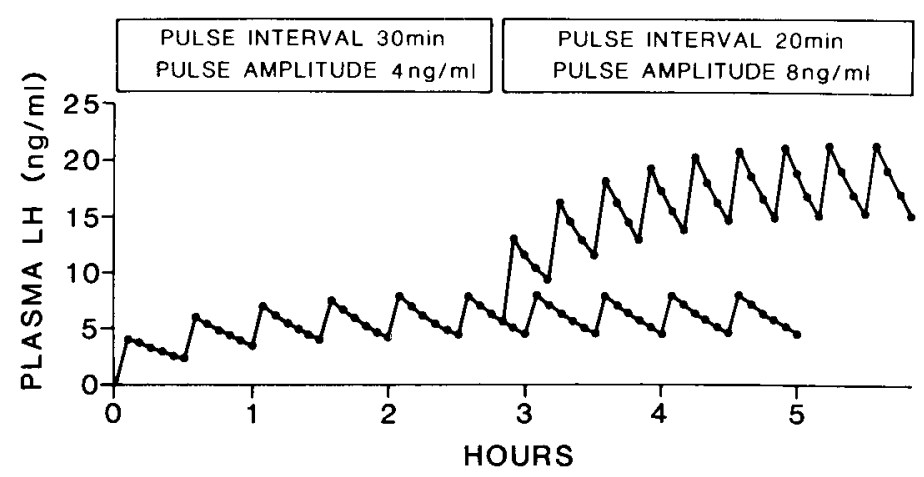

FIG. 1. - Theoretical profiles derived from manually adding and clearing successive pulses. In the first instance (starting at $0 \mathrm{ng} / \mathrm{ml}$ ) the interval between pulses was made equal to the half life of $30 \mathrm{~min}$. It can be seen that the nadirs reach a plateau at about $4 \mathrm{ng} / \mathrm{ml}$ and the peaks reach a plateau at about $8 \mathrm{ng} / \mathrm{ml}$. The second case shows the effects of a combination of a decrease in pulse interval (to less the half life) and an increase in pulse amplitude. 
The asymptotic value for pulse height can be obtained by adding $A$ to $N_{\text {asymp }}$. The existence of an asymptote is perhaps the most striking feature of this relationship, especially when the pulse frequency is reduced to less than one halflife (fig. 1). The concentration does not continue to build up indefinitely, as would be judged intuitively, because the half-life dictates a steeper disappearance curve at higher concentrations than at lower concentrations. For example, with $\mathrm{t}_{1 / 2}=30 \mathrm{~min}$ the concentration must fall by $10 \mathrm{ng} / \mathrm{ml}$ in $30 \mathrm{~min}$ if the starting point is $20 \mathrm{ng} / \mathrm{ml}$ but only $1 \mathrm{ng} / \mathrm{ml}$ in $30 \mathrm{~min}$ if the starting point if $2 \mathrm{ng} / \mathrm{ml}$. The nadir and pulse height therefore level off as they approach asymptotic values determined by a new equilibrium between the rates of clearance (half-life) and secretion (pulse interval and amplitude).

By substituting values into the equation, we were able to study the effects of changes in each of the variables on the final concentrations of $\mathrm{LH}$ that would be achieved, and these have been displayed as the series of lines in figure 2 . For reference, amplitudes of $4 \mathrm{ng} / \mathrm{ml}$ are normally observed during tonic secretion in

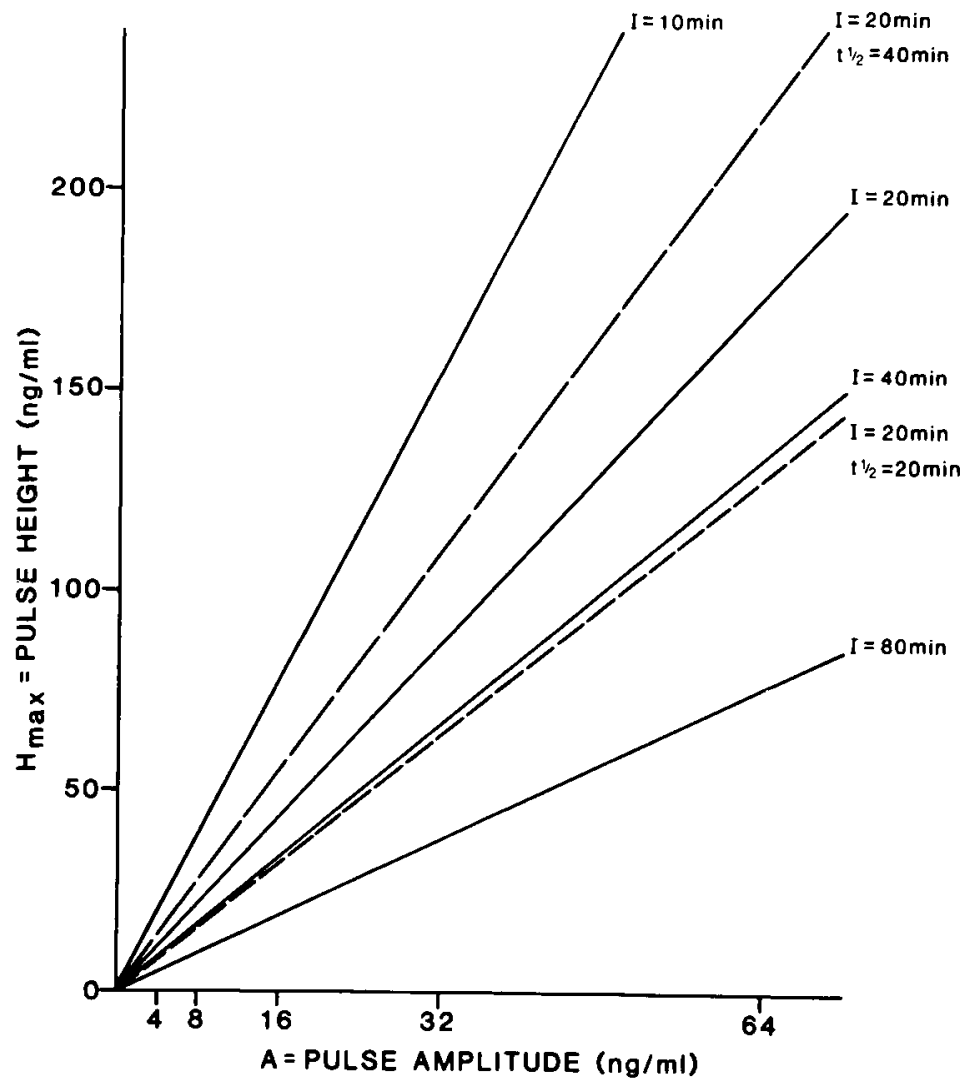

FIG. 2. - Examples of the theoretical relationships between pulse amplitude (A), pulse interval (I), half life $(\mathrm{t} 1 / 2)$ and the maximum concentration reached by the peaks of a series of pulses $\left(\mathrm{H}_{\mathrm{max}}\right)$. The solid lines demonstrate the effect of changing the pulse interval while keeping the half life constant at $30 \mathrm{~min}$, and the two broken lines demonstrate the effects of changing the half life while keeping the interval constant. 
seasonal anoestrus or the luteal phase of oestrous cycle of Merino ewes (Martin et al., 1980 ; Thomas et al., 1987) whereas $32 \mathrm{ng} / \mathrm{ml}$ is somewhat higher than that observed in ovariectomized Merino ewes (Martin et al., 1983). Intervals are typically over 80 min during the luteal phase or anoestrus, and 40 min during the follicular phase (Martin et al., 1980 ; Thomas et al., 1987), but may be as low as 20-30 min during the follicular phase in (Baird, 1978 ; Karsch et al., 1983) or after ovariectomy (Martin et al., 1983). A wide range of half-lives has been reported for $\mathrm{LH}$ in entire ewes, from $23 \mathrm{~min}$ (Geschwind and Dewey, 1968) to $43 \mathrm{~min}$ (Akbar et al., 1974). In anoestrous Merinos, the disappearance curves following endogenous tonic pulses indicate a half-life between these values (Martin, 1981) so values of 20 to $40 \mathrm{~min}$ were substituted into the equation.

\section{Results.}

\section{Experimental observations}

The LH surges from the five Merino ewes are shown in figure 3 . The sampling period coincided with the entire surge only in ewe 1, while the peaks and either the ascending or descending phases were observed in the other four ewes. The mean ( \pm s.e.m.) peak height was $126 \pm 5 \mathrm{ng}$ ( $\mathrm{n}=5$, range 108$141 \mathrm{ng} / \mathrm{ml}$ ) for the Merinos. It was clearly evident that the surge did not consist of smooth increases or decreases in the concentration of LH in any of the ewes, but was composed of pulsatile fluctuations.

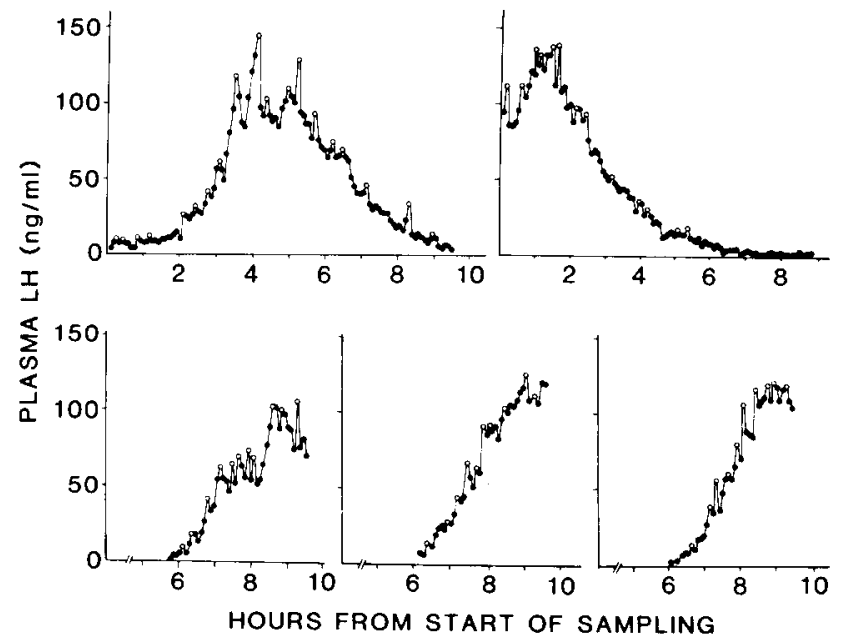

FIG. 3. - The preovulatory surge of $\angle H$ in 5 entire Merino ewes. Samples were collected at $5 \mathrm{~min}$ intervals, beginning at the first sign of oestrous behaviour. The points indicated by open circles (o) are the peaks of significant puises as detected by the pulse definition described in the text.

In the Merinos, the last stages of the follicular phase were observed for 145310 min prior to the onset of the surge, giving a total of $12 \mathrm{~h}$ observation (table 1). For pulse intervals, there was no significant difference between the pre- 
surge period and the ascending phase of the surge, but during the descending phase they became significantly $(P<0.005$, Chi-square) longer than during either of the previous phases. Of the intervals recorded, $30 \%$ were 10 min (i.e., 2 sampling periods) before the onset of the surge, $26 \%$ during the ascent, but only $5 \%$ during the descent. Similarly, $10 \%, 12 \%$ and $32 \%$ of the longer intervals (more than $30 \mathrm{~min}$ ) were observed prior to the surge, during the ascent, and during the descent respectively.

\section{TABLE 1}

LH pulse frequencies, intervals (min) and amplitudes $(\mathrm{ng} / \mathrm{ml}$ ) observed in the jugular plasma of entire Merino and Crossbred ewes around the peak of the preovulatory surge of $L H$.

\begin{tabular}{|c|c|c|c|c|c|c|}
\hline & \multirow{2}{*}{$\begin{array}{l}\text { Pulses } \\
\text { observed }\end{array}$} & \multirow{2}{*}{$\begin{array}{l}\text { Frequency } \\
\text { pulses } / 12 \mathrm{~h}\end{array}$} & \multicolumn{2}{|c|}{ Pulse interval } & \multicolumn{2}{|c|}{ Pulse amplitude } \\
\hline & & & median & range & median & range \\
\hline $\begin{array}{l}\text { - } 12 h \text { to } 6 \text { h before surge } \\
\text { Crossbred }(n=2)\end{array}$ & $24 / 720 \mathrm{~min}$ & 24.0 & 22.8 & $8-60$ & 0.8 & $0.3-2.5$ \\
\hline $\begin{array}{l}-6 \mathrm{~h} \text { to onset of surge } \\
\text { Merino }(\mathrm{n}=3) \\
\text { Crossbred }(n=2)\end{array}$ & $\begin{array}{l}30 / 720 \mathrm{~min} \\
23 / 720 \mathrm{~min}\end{array}$ & $\begin{array}{l}30.0 \\
23.0\end{array}$ & $\begin{array}{l}17.5 \\
17.6\end{array}$ & $\begin{array}{l}10-55 \\
8-108\end{array}$ & $\begin{array}{l}0.7 \\
0.8\end{array}$ & $\begin{array}{l}0.3-1.3 \\
0.2-4.2\end{array}$ \\
\hline $\begin{array}{l}\text { Ascending phase of surge } \\
\text { Merino }(n=5) \\
\text { Crossbred }(n=2)\end{array}$ & $\begin{array}{l}38 / 825 \min \\
29 / 484 \min \end{array}$ & $\begin{array}{l}33.2 \\
43.0\end{array}$ & $\begin{array}{l}18.3 \\
15.2\end{array}$ & $\begin{array}{r}10-55 \\
8-56\end{array}$ & $\begin{array}{l}18.0 \\
35.0\end{array}$ & $\begin{array}{l}4.0-69.0 \\
4.4-92.4\end{array}$ \\
\hline $\begin{array}{l}\text { Descending phase of surge } \\
\text { Merino }(\mathrm{n}=2) \\
\text { Crossbred }(n=2)\end{array}$ & $\begin{array}{l}21 / 590 \min \\
23 / 510 \min \end{array}$ & $\begin{array}{l}25.6 \\
32.1\end{array}$ & $\begin{array}{l}22.5 \\
15.2\end{array}$ & $\begin{array}{r}10-70 \\
8-56\end{array}$ & $\begin{array}{r}8.1 \\
15.2\end{array}$ & $\begin{array}{l}3.0-32.0 \\
0.8-94.5\end{array}$ \\
\hline $\begin{array}{l}\text { After surge } \\
\quad \text { Crossbred }(\mathrm{n}=1)\end{array}$ & $18 / 308 \mathrm{~min}$ & 42.1 & 20.0 & $8-32$ & 0.8 & $0.3-1.5$ \\
\hline
\end{tabular}

The pre-surge period was characterized by pulses of very low amplitude and, although the use of different assay methods precluded rigorous statistical comparison, it was quite evident that the amplitudes increase at least 5 -fold at the onset of the surge. The amplitudes were significantly $(P<0.005$, Chi-squared) greater during the ascending phase of the surge than during the descending phase. Of the pulses recorded, $42 \%$ had amplitudes greater than $20 \mathrm{ng} / \mathrm{ml}$ during the ascent, but only $23 \%$ during the descent.

In figure 4, the frequency distributions of pulse intervals for the late follicular phase and the surge are compared for the Merinos. These distributions were very similar with similar median values. Figure 4 also illustrates the changes in pulse interval during the surge itself, in relation to the time the peak is attained. There was a large degree of variation in pulse interval, but it appeared to be shortest during the ascending phase, particularly around the time of the third and fourth pulses before the peak when the mean was $12.5 \pm 2.2 \mathrm{~min}$. In contrast to the data for interval, there was a distinct pattern in the pulse amplitudes. The amplitude of the eighth pulse before the peak was already well outside the range of the late follicular phase, and there was another sharp increase in the next pulse ( $P<0.05$, paired test) followed by a gradual rise to a maximum of 
$32.6 \pm 8.7 \mathrm{ng} / \mathrm{ml}$ for the pulse giving the peak concentration. The amplitude then declined during the descending phase.
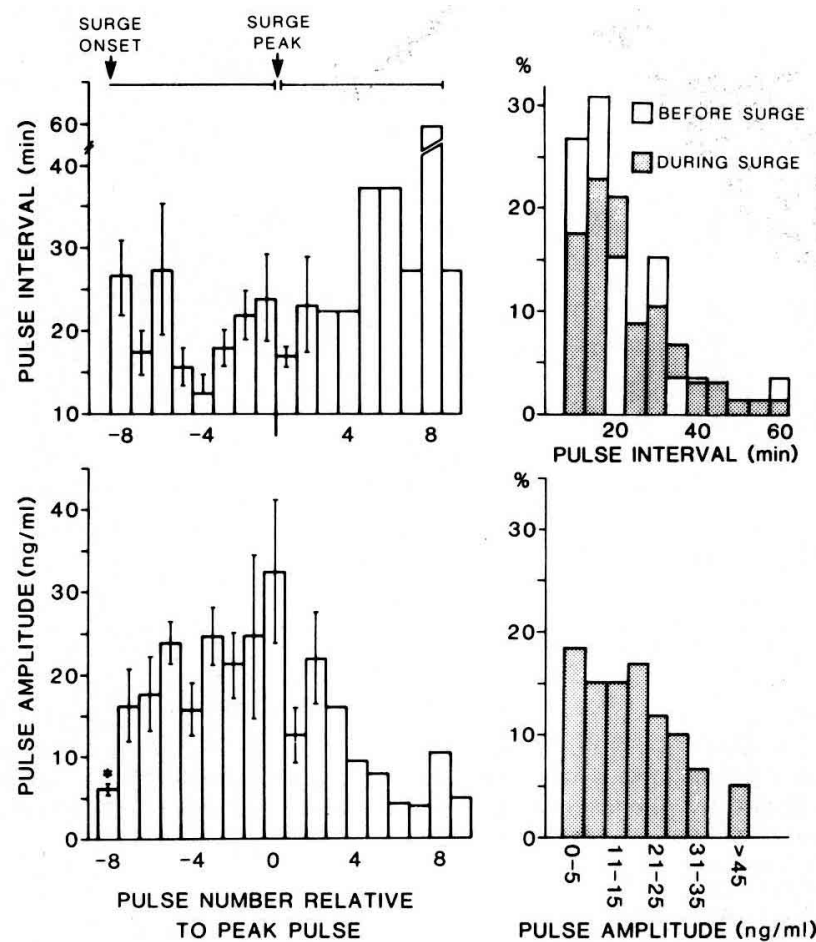

PULSE AMPLITUDE $(\mathrm{ng} / \mathrm{ml})$

FIG. 4. - Left pane/s - The changes in pu/se interval (top) and pulse amplitude (bottom) observed during the ascending and descending phases of the $L H$ surge, plotted in relation to the pulse which provided the highest concentration recorded during the surge (" keak pulse ", or Pulse O) ; Right pane/s - Frequency distributions of $L H$ pulse intervals (top), before and during the surge, and pulse amplitudes (bottom) observed during the $\mathrm{LH}$ surge. The frequency distribution for amplitudes observed in the late follicular phase are not shown as all pulses fell in the first category $(0-5 \mathrm{ng} / \mathrm{ml})$ on the extreme left of the distribution. The bars indicate standard errors and the asterisk indicates $P<0.05$ (paired test) for the change in amplitude between the 8th and 7 th pulses before the peak of the surge.

The sections of the profiles containing the surges of the crossbred ewes are shown in figure 5 and the data for the late follicular phase are in table 1. Again the pulsatile nature of $\mathrm{LH}$ secretion during the surge is evident. The peak concentrations were $135 \mathrm{ng} / \mathrm{ml}$ and $173 \mathrm{ng} / \mathrm{ml}$ and the pulse intervals and amplitudes varied between the phases in similar fashion to those of the Merinos (table 1). The most striking change was in pulse amplitude. The median value was less than $1 \mathrm{ng} / \mathrm{ml}$ before the onset of the surge and increased to $35.0 \mathrm{ng} / \mathrm{ml}$ during the ascending phase, which was characterized by a proportion of very high amplitude pulses e.g., $68 \%$ were over $20 \mathrm{ng} / \mathrm{ml}$ and $32 \%$ were over $60 \mathrm{ng} / \mathrm{ml}$. During the descending phase, these proportions decreased to $39 \%(P<0.05$, Chi-squared) and $9 \%(P<0.01)$ respectively. In general, during the surge the intervals were shorter and the amplitudes higher in the crossbreds than in the Merinos, the latter despite the use of the same LH standard preparation in the 
assay. Overall, $15 \%$ of the puise intervals recorded were 2 sampling intervals long for the crossbreds and $19 \%$ for the Merinos.

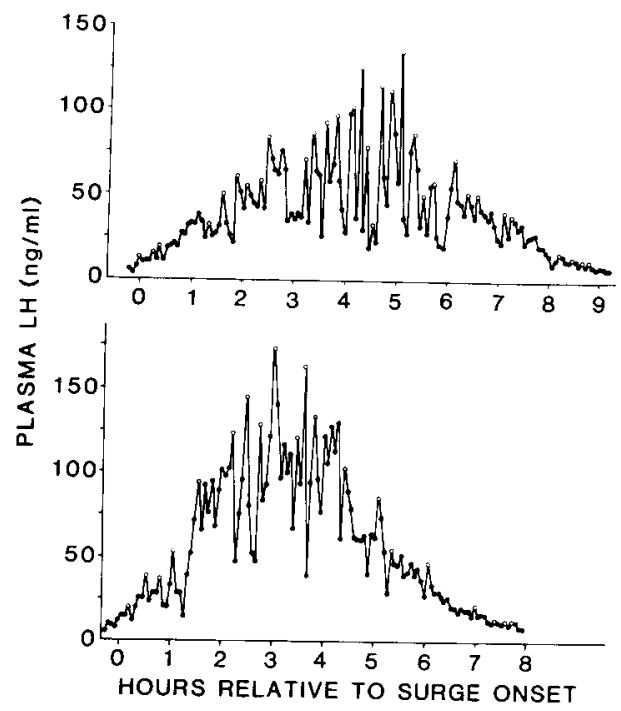

FIG. 5. - The LH surges of 2 entire Romanov $\times$ Préalpes-du-Sud ewes. Blood was sampled continuously and pooled over $4 \mathrm{~min}$ intervals, beginning at the first sign of oestrous behaviour. The points indicated by open circles $(0)$ are the peaks of significant pulses as detected by the pulse definition described in the text.

\section{Theoretical study}

Figure 2 shows the theoretical effects of changing the hormone half-life and the frequency and amplitude of pulses on the maximum pulse height that can be achieved. With a half-life of $30 \mathrm{~min}$, it can be seen that to reach concentrations normally observed during the $\mathrm{LH}$ surge (over $100 \mathrm{ng} / \mathrm{ml}$ ), either pulse frequency or pulse amplitude must be increased to well above the normal range i.e., above the values observed in other physiological states. Changes in the rate of clearance could have considerable impact on the ability of pulses to achieve high concentrations (fig. 2) even if it is limited to the range of values reported in the literature. However, even with the longest half-life $(40 \mathrm{~min})$, either amplitude or frequency must still be increased above the normal range if concentrations around $100 \mathrm{ng} / \mathrm{ml}$ are to be reached, and for higher concentrations both pulse variables must be changed. If the half-life was $20 \mathrm{~min}$ or less, both amplitude and frequency would have to be above normal.

\section{Discussion.}

In this study we have confirmed the suggestions of earlier reports that $\mathrm{LH}$ is secreted in a pulsatile manner throughout the preovulatory surge in the ewe and we have expanded upon this by showing : 1) that the initiation, maintenance and 
termination of the surge could be explained by changes in pulse amplitude, provided the frequency is sufficiently high ; 2 ) that the amplitudes (and probably frequencies) required lie well above the range observed in other physiological situations ; 3) that if LH is secreted only as pulses, the surge cannot be initiated by simply reducing the pulse interval to less than the half-life of the hormone.

It could be argued that the empirical observations are drawn from only a few complete surges from a few animals. Indeed, experiments of this type are difficult to design, particularly with respect to prediction of the timing of the surge, and lead to a large number of samples spanning a very wide range of concentrations, which need to be included in a single assay run to aid pulse analysis. However, despite these problems and the differences between the experiments in assay and sampling protocol, all of the surges observed were strikingly similar, showing similar frequencies and amplitudes and the same phenomenon of a sudden increase in amplitude superimposed on a background of high frequency at the onset of the surge.

The sudden increase in LH pulse amplitude at the onset of the surge reflects an increase in the responsiveness of the anterior pituitary gland to $\mathrm{GnRH}$ rather than an increase in the amplitude of the GnRH pulses secreted into stalk blood (Clarke and Cummins, 1984). Pituitary responsiveness increases in a time- and dose-dependent manner in response to the high levels of plasma oestrogen just prior to the onset of the surge (Reeves et al., 1971 ; Jackson, 1975 : Coppings and Malven, 1976), an effect which is apparently mediated by an increase in the number of $\mathrm{GnRH}$ receptors (Schoenemann et al., 1985). It may also increase through the mechanism of self-priming (Crighton and Foster, 1977), though on currently available evidence it is difficult to assess the contribution of this phenomenon to the initiation of the surge (Martin, 1984). The descent from the peak of the surge appears to be due primarily to a decline in amplitude and this effect is also mediated at the level of the pituitary gland. It has been shown that the anterior pituitary gland responds very weakly to exogenous $\mathrm{GnRH}$ following the surge (Foster and Crighton, 1976), possibly due to pituitary exhaustion or to the down-regulation of $\mathrm{GnRH}$ on the gonadotrophs (Clayton et al., 1980).

Whereas the amplitude changes associated with the surge have been clearly demonstrated in the present study, we need to rely upon comparisons with data from other experiments from our laboratories to implicate a role for changes in pulse frequency. We do so cautiously for several reasons : first, although the assays used in this and previous studies are comparable, the systems for blood sampling and pulse detection are not; second, in the present study we were unable to demonstrate any major changes in frequency during the period around the onset of the surge ; and finally, the theoretical study suggests that if the frequency were held constant at the median values observed in the present experiments, the surge could be completely explained by changes in amplitude. However, it is evident from the profiles, especially on the steeper sections of the ascending and descending phases, that there were many small fluctuations in $\mathrm{LH}$ levels, often indicated by departures from the rapid increases and exponentialtype decreases in concentration normally associated with pulsatile secretion, which did not qualify as pulses under the definition used here. We suspect that 
these were in fact pulses and that because they were not detected the overall pulse frequency was underestimated. This is supported by the highly variable intervals observed within a given profile. Acceptance of frequencies which are higher than the measured values strengthens the theoretical argument that the surge could be expressed purely by changes in amplitude. However, this same problem of inadequate pulse detection weakens the empirical argument of a constant frequency throughout the surge, especially since the pulse interval tended to be shorter during the ascending phase.

Obviously, this matter cannot be definitively resolved with the present data, but we can still address one of the purposes of this study, namely to compare the amplitudes and frequencies in the surge with those normally secreted by ewes during other stages of the reproductive cycle. A significant proportion of the pulse intervals were only 2 sampling intervals long, i.e. in the order of 8-10 $\mathrm{min}$, and most were less than $30 \mathrm{~min}$. For pulse amplitude, values of $30-90 \mathrm{ng} / \mathrm{ml}$ were common, and a large number fell within the range $16-32 \mathrm{ng} / \mathrm{ml}$. Thus, despite the difficulty of obtaining accurate measures of the frequencies and amplitudes, it appears that both are greater than those observed at any other stage of the reproductive cycle, and also greater than those observed in ovariectomized ewes where the generally inhibitory effects of the ovarian steriods have been removed.

A frequency above that seen in other reproductive states suggests that hypothalamic stimulation plays an active role in the positive feedback mechanism of the ewe. This is supported by other lines of evidence : first, knife cuts placed in the retrochiasmatic area obliterate or reduce the size of the LH surge (Thiery et al., 1978 ; Jackson et al., 1978 ; Pau et al., 1982); second, the surge induced in ovariectomized ewes by exogenous oestrogen is accompanied by an increase in the multiunit activity of the retrochiasmatic area associated with pulsatile LH release (Thiery and Pelletier, 1981) and by an increase in the irequency, but not the amplitude, of $\mathrm{GnRH}$ pulses secreted into hypophyseal stalk portal blood (Clarke and Cummins, 1985) ; third, treatment of ewes with barbiturate during the ascending phase of the surge will reduce the secretion of LH (Webb et al., 1981) ; and fourth, in ovariectomized ewes in which the hypothalamus and pituitary gland have been surgically disconnected and endogenous $\mathrm{GnRH}$ has been replaced by a regime of constant hourly injections of $\mathrm{GnRH}$, the $\mathrm{LH}$ surge evoked by oestrogen is smaller than that seen in the entire ewe (Clarke and Cummins, 1984). Taken together, this evidence indicates that the LH surge of the ewe is at least partly dependent on the action of oestrogen on hypothalamic sites, although the data from the present study suggest that pulse frequency is close to a maximum before the onset of the surge per se, which begins when the gonadotrophs are sufficiently responsive to $\mathrm{GnRH}$ to be able to secrete high amplitude pulses.

During the descending phase of the surge there is some indication of a decline in pulse frequency. However, once the peak has been attained pulse amplitude falls very rapidly thereby reducing the efficiency with which the pulses are detected, so the pulse frequency is probably underestimated to a greater degree during the descending phase than during the other phases. We therefore propose that the decline in LH levels is due mainly to pituitary effects. This is 
supported by the observation that multiunit activity in the hypothalamus remains high during this phase (Thiery and Pelletier, 1981) and that barbiturate anaesthesia after the apex of the surge does not accelerate the decline in plasma LH levels (Webb et al., 1981). Finally, despite the problems with pulse detection in the present study, the frequencies observed during the descending phase of the surge were greater than those previously seen in ovariectomized ewes.

A change in the rate of clearance of $\mathrm{LH}$, even within the range of published values, could also make a significant contribution to the mechanism of the surge. To date, the half-life of $\mathrm{LH}$ secreted during the surge has not been measured, but the literature contains ample evidence for physiological control of the form of $\mathrm{LH}$ released. For example, the amount of carbohydrate residue in glycoprotein hormones is a major determinant of the rate of clearance of the hormone (Van Hall et al., 1971) and appears to be under oestrogenic control in primates and rats (Peckham and Knobil, 1976 ; Weick, 1977). Similarly, in sheep it is known that the rate of disappearance of $\mathrm{LH}$ following a pulse decreases with time after ovariectomy, indicating a reduction in the rate of clearance (Montgomery et al., 1984). These observations suggest that oestrogen reduces the carbohydrate content and thereby reduces the half-life of the $\mathrm{LH}$ being released. It seems plausible for this to be one of the ways by which the anterior pituitary gland is prepared for the surge by the high levels of oestrogen secreted during the late follicular phase. A decrease in the half-life of the hormone would make it more difficult to achieve and maintain high levels of $\mathrm{LH}$, but it would also prevent high frequency pulses from merging with one another. Our data, particularly those from the crossbred ewes, support this contention because many of the declines following peaks of pulses appear to be far steeper than can be accounted for by a half-life of $20 \mathrm{~min}$. This is a subject for future investigation.

Reçu en novembre 1986.

Accepté en septembre 1987.

Acknowledgements. - We thank the following people for their valuable assistance during the experimental work: Mrs. F. Bertholet; Dr. C. M. Oldham; Prof. D. R. Lindsay; Mr. P. Moore and Mr. D. Suckling. Our thanks also to Dr. P. L. Taylor of the MRC, who assisted with the analysis of the data, and Mr. R. Nowak, who prepared the Résumé. The Australian Meat Research Committee funded the work on Merino sheep in Australia and supported GBM with an Overseas Study Award.

Résumé. Sécrétion pulsatile de $L H$ durant la décharge ovulante chez la brebis. Observations experimentales et considérations théoriques.

Il a été démontré chez plusieurs espèces que la sécrétion de LH au cours de la décharge préovulatoire est pulsatile. Nous avons confirmé ce phénomène chez des brebis intactes au cours de deux expériences où nous avons étudié en détail la décharge de LH. Dans la première expérience, les taux de LH ont été mesurés dans des échantillons de plasma de sang prélevés toutes les 5 min avant et au cours de l'oestrus de 5 brebis Méri- 
nos. Pendant 2 à $5 \mathrm{~h}$, immédiatement avant le début du pic de LH, la médiane de l'intervalle entre les pulses était 17,5 min (valeurs extrêmes : 10-55 min) et la médiane de l'amplitude des pulses était de $0,70 \mathrm{ng} / \mathrm{ml}$ (valeurs extrêmes : $0,28-1,33 \mathrm{ng} / \mathrm{ml}$ ). Pendant la phase ascendante de la décharge, l'intervalle entre les pulses n'a pas varié significativement (médiane : 18,3 min) cependant la médiane de l'amplitude des pulses a augmenté jusqu'à $18,0 \mathrm{ng} / \mathrm{ml}$. Pendant la phase descendante, la médiane de l'intervalle entre les pulses était 22,5 min et la médiane de l'amplitude a chuté jusqu'à $8,1 \mathrm{ng} / \mathrm{ml}(\mathrm{P}<0,005)$. Des intervalles de $10 \mathrm{~min}$ et des amplitudes de plus de $30 \mathrm{ng} / \mathrm{ml}$ étaierit souvent enregistrés au cours de la décharge hormonale. Dans la seconde expérience, effectuée sur deux brebis Romanov $x$ Préalpes-du-Sud en oestrus, le sang a été prélevé continuellement grâce à une pompe et des échantillons correspondant à 4 min ont été réalisées grâce à un collecteur de fractions, ceci pendant une période de 19 à $27 \mathrm{~h}$. Les profils hormonaux ont montré des pulses individuels plus clairs, cependant la fréquence (médiane durant la phase ascendante : 15,2 min) et l'amplitude (médiane : $35,0 \mathrm{ng} / \mathrm{ml}$ ) ont varié tout comme chez le Mérinos.

En utilisant un modèle mathématique simple de la sécrétion pulsatile de $\mathrm{LH}$, et en supposant que la LH est exclusivement libérée sous forme de pulse, nous avons également trouvé que les concentrations élevées normalement observées au cours de la décharge ne peuvent être expliquées que par des fréquences de pulse et d'amplitude bien supérieures à celles normalement observées dans d'autres conditions physiologiques telles que la phase folliculaire ou l'ovariectomie. La comparaison de ces résultats avec les données expérimentales nous a conduit à conclure que l'initiation ainsi que la réalisation de la décharge préovulatoire de LH sont probablement dues à des changements d'amplitude des pulses. Une fréquence rapide est également nécessaire mais nos résultats suggèrent que cela peut être établi bien avant le déclenchement de la décharge elle-même. Ces changements reflètent respectivement les composantes hypophysaire et hypothalamique du mécanisme du rétro-contrôle positif. L'étude théorique a suggéré qu'un changement dans la vitesse de dégradation peut également contribuer au phénomène de la décharge préovulatoire et ceci nécessite des recherches ultérieures.

\section{Annex.}

Detailed description of empirical study. - Following logarithmic (In) transformation of the concentration/time curve (fig. 6), the decline in hormone levels is described by a straight line,

or $\ln C=a-b t$

$$
\ln C^{\prime}-\ln C^{\prime \prime}=b\left(t^{\prime \prime}-t^{\prime}\right)
$$

Put $\mathrm{t}^{\prime}=0$ and $\mathrm{t}^{\prime \prime}=\mathrm{t}_{1 / 2}$ so that $\mathrm{C}^{\prime}=2 \mathrm{C}^{\prime \prime}$

i.e., $\ln C^{\prime}=\ln 2+\ln C^{\prime \prime}$. Substitute for $\ln C^{\prime}$ in [1],

$$
b=\frac{\ln 2}{t_{1 / 2}}
$$

Taking antilogarithms in [1],

$$
\frac{C^{\prime}}{C^{\prime \prime}}=e^{b\left(t^{\prime \prime}-t^{\prime}\right)}
$$

where $e$ is the exponent 2.718. Substituting for $b$ from expression [2]

$$
C^{\prime \prime}=\frac{C^{\prime}}{e^{\left[\ln 2\left(t^{\prime \prime}-t^{\prime}\right) / t_{1 / 2}\right]}}
$$

where $C^{\prime}$ is the pulse height and $C^{\prime \prime}$ is the level $t^{\prime \prime}$ min after the peak is reached (fig. 6). This expression can be used to calculate the decay curve following a pulse and, after a series of manual 
calculations, show how LH levels change following a change in pulse interval and amplitude. An example of this effect is plotted in figure 1 , where we used $t_{1 / 2}=30 \mathrm{~min}$, a convenient figure close to the published estimates in entire ewes (Geschwind and Dewey, 1968; Akbar et al., 1974).
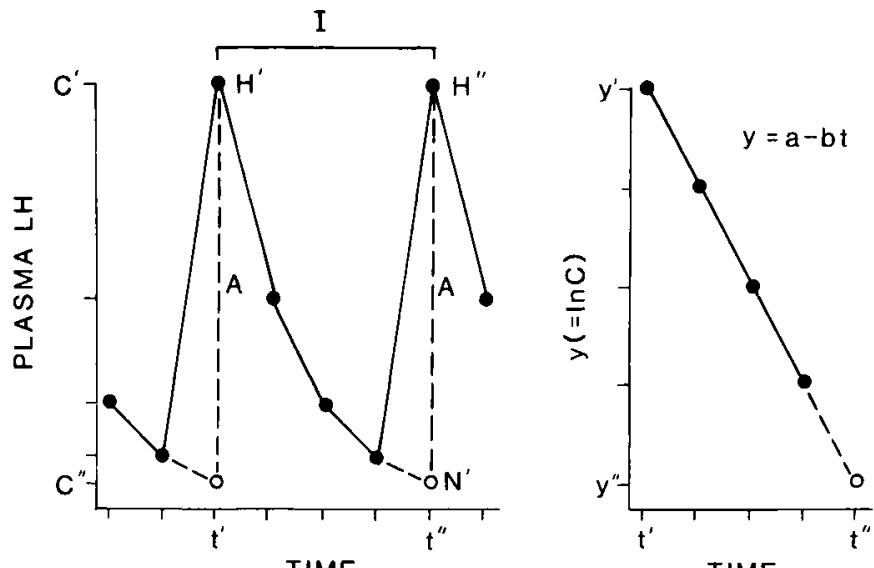

TIME

TIME

FIG. 6. - The theoretical LH pulse, showing it's relationship with sample points and the linearization of the disappearance curve. The solid line indicates the form which would be observed by discrete sampling and the broken line indicates the form assumed for the calculations.

$\mathrm{C}$ : concentration of $\mathrm{LH} ; \mathrm{t}$ : time ; $\mathrm{A}$ : amplitude : $\mathrm{I}$ : pulse interval $\mathrm{H}$ : pulse height concentration : $\mathrm{N}$ : nadir concentration : $\mathrm{a}$ : intercept on ordinate axis ; $\mathrm{b}$ : slope of the regression line $; t_{1 / 2}:$ half life.

These manipulations and their consequences can also be described mathematically. Starting with a conveniently chosen concentration, $S 10 \mathrm{ng} / \mathrm{ml}$ in the first case in figure 1), theoretical pulses are added and cleared (a time series) until a picture of the changes in nadir and pulse height following a change in frequency and amplitude are built up. If we fix pulse interval at I and pulse amplitude at $A$ then the "theoretical nadir " $(\mathrm{N}$ ") following the first pulse is obtained by substituting $\mathrm{N}$ " for $\mathrm{C}$ ", $(S+A)$ for $C^{\prime}$, and $\left(\right.$ for $\left(t^{\prime \prime}-t^{\prime}\right)$ in (3) giving :

$$
N^{\prime \prime}=\frac{(S+A)}{e^{b l}}
$$

The assumption of instantaneous secretion and mixing allows the amplitude to be added directly to the theoretical nadir, the concentration at the instant of secretion, giving the height of the second pulse (using (5)) :

$$
H^{\prime \prime}=\frac{(S+A)}{e^{b t}}+A
$$

Repeating these operations (dividing by $\mathrm{e}^{\mathrm{bl}}$ to obtain the next nadir and adding $A$ for the pulse height) for each pulse in turn, one obtains an expression for the theoretical nadir (N) after j pulses :

$$
\begin{aligned}
N_{(j \text { pulses })} & =\frac{S+A}{\left[e^{b 1}\right]^{i-1}}+\frac{A}{\left[e^{b l}\right]^{j-2}}+\cdots+\frac{A}{e^{b l}} \\
& =\frac{A\left(1-\left[e^{b l}\right]^{-j}\right)}{e^{b l-1}}+S\left[e^{b l}\right]^{-j}
\end{aligned}
$$

Obviously, as the number of pulses (j) increases the term $\left(e^{b \mid}\right)^{-j}$ in (6) tends to zero, and the nadir stabilizes at its asymtotic (asymp) maximum :

$$
N_{\text {asymp }}=\frac{A}{e^{b l-1}}
$$

where $A, 1$ and $t_{12}$ are fixed and, from (2) $b=\frac{\ln 2}{t_{1 / 2}}$ 
The asymptotic value for pulse height can be obtained by adding the amplitude to $\mathrm{N}_{\text {asymp }}$. The series of lines in figure 2 were obtained by substituting values into equation (7) as described in the Materials and Methods.

\section{References}

AKBAR A. M., NETT T. M., NISWENDER G. D., 1974. Metabolic clearance and secretion rates of gonadotropins at different stages of the estrous cycle in ewes. Endocrinology, 94, 1310-1324.

BAIRD D. T., 1978. Pulsatile secretion of LH and ovarian estradiol during the follicular phase of the sheep estrous cycle. Biol. Reprod., 18, 359-364.

CLARKE I. J., CUMMINS J. T., 1984. Direct pituitary effects of estrogen and progesterone on gonadotropin secretion in the ovariectomized ewe. Neuroendocrinology, 39, 267-274.

CLARKE I. J., CUMMINS J. T., 1985. Increased gonadotropin-releasing hormone pulse frequency associated with estrogen-induced LH surges in ovariectomized ewes. Endocrinologv, 116, 2376-2383.

CLAyTON R. H., SOlANO A. R., GARCIA-VELA A., DUFAU M. L., CATT K. J., 1980. Regulation of pituitary receptors for gonadotropin-releasing hormone during the rat estrous cycle. Endocrinology, 107, 699-706.

COPPINGS R. J., MALVEN P. V., 1976. Biphasic effect of estradiol on mechanisms regulating LH release in ovariectomized sheep. Neuroendocrinology, 21, 146-156.

CRIGHTON D. B., FOSTER J. P., 1977. Luteinizing hormone release after two injections of synthetic luteinizing hormone releasing hormone in the ewe. J. Endocr., 72, 59-67.

FOSTER J. P., CRIGHTON D. B., 1976. Pituitary responsiveness to a single injection of synthetic luteinizing hormone-releasing hormone before and after the preovulatory plasma luteinizing hormone peak in sheep. J. Endocr., 71, 269-270.

GALLO R. V., 1981. Pulsatile LH release during the ovulatory LH surge on proestrus in the rat. Biol. Reprod., 24, 100-104.

GESCHWIND I. I., DEWEY R., 1968. Dynamics of luteinizing hormone (LH) secretion in the cycling ewe : a radioimmunoassay study. Proc. Soc. exp. Biol., Med., 129, 451-459.

JACKSON G. L., 1975. Blockage of estrogen-induced release of LH by reserpine and potentiation of synthetic gonadotropin-releasing hormone-induced release of luteinizing hormone by estrogen in the ovariectomized ewe. Endocrinology, 97, 1300-1307.

JACKSON G. L., KUEHL D., McDOWELL K., ZALESKI A., 1978. Effect of hypothalamic deafferentation on secretion of luteinizing hormone in the ewe. Biol. Reprod., 18, 808-819.

KARSCH F. J., FOSTER D. L., BITTMAN E. L., GOODMAN R. L., 1983. A role for estradiol in enhancing luteinizing hormone pulse frequency during the follicular phase of the estrous cycle of sheep. Endocrinology, 113, 1333-1339.

McINTOSH J. E. A., McINTOSH R. P., 1980. Mathematical modelling and computers in endocrinology. In Monographs of Endocrinology, vol. 16, pp. 115-119. Springer-Verlag, Berlin.

MARTIN G. B., 1981. Factors affecting the secretion of luteinizing hormone in the ewe. Ph. D. Thesis. Univ. Western Australia.

MARTIN G. B., 1984. Factors affecting the secretion of luteinizing hormone in the ewe. Biol. Rev., 59. 1-87.

MARTIN G. B., OLDHAM C. M., LINDSAY D. R., 1980. Increased plasma LH levels in seasonally anovular Merino ewes following the introduction of rams. Anim. Reprod. Sci., 3, 125-132.

MARTIN G. B., SCARAMUZZI R. J., HENSTRIDGE J. D., 1983. Effects of oestradiol, progesterone and androstenedione on the pulsatile secretion of luteinizing hormone in ovariectomized ewes during spring and autumn. J. Endocr., 96, 181-193.

MARUT E. L., WILliAMS R. G., COWAN B. D., LYNCH A., LERNER S. P., HODGEN G. D., 1981. Pulsatile pituitary gonadotropin secretion during maturation of the dominant follicle in monkeys : estrogen positive feedback enhances the biological activity of LH. Endocrinology, 109, 2270-2272.

MIDGLEY JNR A. R., JAFFE R. B., 1971. Regulation of human gonadotropins. X. Episodic fluctuation of LH during the menstrual cycle. J. clin. Endocr., 33, 962-929. 
MONTGOMERY G. W., CROSBIE S. F., MARTIN G. B., PELLETIER J., 1984. Changes in the clearance of immunoreactive LH after ovariectomy in lle-de-France ewes. In LINDSAY D. R., PEARCE D. T., Reproduction in sheep, pp. 23-25. Austr. Acad. Sc. Press, Canberra.

NISWENDER G. D., ROCHE J. F., FOSTER D. L., MIDGLEY JNR A. R., 1968. Radioimmunoassay of serum levels of tuteinizing hormone during the cycle and early pregnancy in ewes. Proc. Soc. exp. Biol. Med., 129, 901-904.

PAU K.-Y. F., KUEHL D., JACKSON G. L., 1982. Effect of frontal hypothalamic deafferentation on luteinizing hormone secretion and seasonal breeding in the ewe. Biol. Reprod., 27, 9991010.

PECKHAM W. D., KNOBIL E., 1976. The effects of ovariectomy, estrogen replacement and neuraminidase treatment on the properties of the adenohypophysial glycoprotein hormones of the Rhesus monkey. Endocrinology, 98, 1054-1060.

PELLETIER J., KANN G., DOLAIS J., ROSSELIN G., 1968. Dosage radioimmunologique de l'hormone luteinisante plasmatique chez le mouton. Comparaison avec le dosage biologique de LH par la diminution de l'acide ascorbique ovarien, et exemple d'application aux mesures de la LH sanguine chez la brebis. C.R. Acad. Sci. (Paris), 266, 2352.

PELLETIER J., GARNIER D. H., de REVIERS M.-T., TERQUI M., ORTAVANT R., 1982. Seasonal variation in $\mathrm{LH}$ and testosterone release in rams of two breeds. J. Reprod. Fert., 64, 341-346.

POINDRON P., COGNIE Y., GAYERIE F., ORgEUR P., OLDHAM C. M., RAVAUT J. P., 1980. Changes in gonadotrophins and prolactin levels in isolated (seasonally or lactationally) anovular ewes associated with ovulation caused by the introduction of rams. Physiol. Behav., 25, 227-236.

RAHE C. H., OWENS R. E., FLEEgER J. L., NEWTON J. T., HARMS P. G., 1980. Pattern of plasma luteinizing hormone in the cyclic cow: dependence upon the period of the cycle. Endocrinology, 107, 498-503

RASMUSSEN D. D., MALVEN P. V., 1982. Characterization of cephalic arteriovenous LH differences by continuous sampling in ovariectomized ewes. Neuroendocrinology, 34, 415-420.

REEVES J. J., ARIMURA A., SCHALLY A. V., 1970. Serum levels of prolactin and luteinizing hormone (LH) in the ewe at various stages of the estrous cycle. Proc. Soc. exp. Biol. Med., 134, 938-942.

REEVES J. J., ARIMURA A., SCHALLY A. V., 1971. Changes in pituitary responsiveness to purified luteinizing hormone-releasing hormone ( $\mathrm{LH}-\mathrm{RH}$ ) in anestrous ewes pre-treated with estradiol benzoate. Biol. Reprod., 4, 88-92.

SCARAMUZZI R. J., CALDWELL B. V., MOOR R. M., 1970. Radioimmunoassay of LH and estrogen during the estrous cycle of the ewe. Biol. Reprod., 3, 110-119.

SCARAMUZZI R. J., MARTENSZ N. D., 1975. The effects of active immunization against androstenedione on luteinizing hormone levels in the ewe. In NIESCHLAG E., Immunization with hormones in reproductive research, pp. 141-152. North-Holland, Amsterdam.

SCHOENEMANN H. M., HUMPHREY W. D., CROWDER M., NETT T. M., REEVES J. J., 1985. Pituitary luteinizing hormone-releasing hormone receptors in ovariectomized cows after challenge with ovarian steroids. Biol. Reprod., 32, 574-583.

THIERY J. C., PELLETIER J., 1981. Multiunit activity in the anterior median eminence and adjacent areas of the hypothalamus of the ewe in relation to LH secretion. Neuroendocrinology, 32 , 217-224.

THIERY J. C., PELLETIER J., SIGNORET J. P., 1978. Effect of hypothalamic deafferentation on LH and sexual behaviour in ovariectomized ewe under hormonally induced oestrous cycles. Ann. Biol. anim. Bioch. Biophys., 18, 1413-1426.

THOMAS G. B., MARTIN G. B., FORD J. R., CAMPBELL B. K., MOORE P. M., 1987. Changes in the plasma concentrations of $\mathrm{LH}, \mathrm{FSH}$, progesterone and oestradiol-17;; of Merino ewes during the oestrous cycle. (In preparation).

VAN HALL E. V., VAITUKAITUS J. K., ROSS G. T., HICKMAN J. W., ASHWELL G., 1971. Immunological and biological activity of HCG following progressive desialylation. Endocrinology, 88, 456-464. 
WALTERS D. L., SCHALLENBERGER E., 1984. Pulsatile secretion of gonadotrophins, ovarian steroids and ovarian oxytocin during the periovulatory phase of the oestrous cycle of the cow. J. Reprod. Fert., 72, 503-512.

WEBB R., ENGLAND B. G., FITZPATRICK K. E., 1981. Control of the preovulatory gonadotropin surge in the ewe. Endocrinology, 108, 1178-1185.

WEICK R. F., 1977. A comparison of the disappearance rates of luteinizing hormone from intact and ovariectomized rats. Endocrinology, 101, 157-161. 